\title{
Studies on lipid digestion in the preruminant calf
}

\author{
2.* A comparison of the products of lipolysis of milk fat by \\ salivary and pancreatic lipases in vitro
}

\author{
BY J. D. EDWARDS-WEBB AND S. Y. THOMPSON \\ National Institute for Research in Dairying, Shinfield, Reading RG2 $9 A T$
}

(Received 23 fune 1976 - Accepted 30 November 1976)

\begin{abstract}
I. A comparison has been made of the products of lipolysis of the fat in cow's milk by salivary and pancreatic lipases $\left(E C C_{3} \cdot \mathrm{I} . \mathrm{I} \cdot 3\right)$ from a preruminant calf.

2. It was confirmed that salivary lipase releases short-chain acids preferentially, particularly butyric and caproic acids. This was not only true initially but also as the course of lipolysis progressed. Even after $60 \mathrm{~min}$ incubation the longer-chain acids were only released to about one-twentieth of the extent of butyric acid.

3. Although pancreatic lipase also initially released proportionately more butyric acid than other fatty acids, within 30 min the longer-chain acids were released to about half the extent of butyric acid.

4. Since the over-all extent of lipolysis by salivary lipase was limited by its inability to release long-chain acids, the release of these acids (which comprise two-thirds of the total fatty acids of milk fat) in the calf is likely to be dependent on the subsequent action of pancreatic lipase.

5. The release of fatty acids by pancreatic lipase was enhanced by pre-incubating milk fat with salivary lipase.
\end{abstract}

Studies on the role of saliva in digestion in the young calf established that lipolysis occurs in milk even before it reaches the stomach (Wise, Miller \& Anderson, 1940, 1947). The oral glands were suggested as the source of this activity (Harper \& Gould, 1955) and it was found that extracts of the glands at the back and root of the tongue and the pharyngeal end of the oesophagus were lipolytic (Ramsey, Wise \& Tove, 1956).

Salivary lipase (EC 3.I.I.3) action continues in the abomasum since, for at least $2 \mathrm{~h}$ after a meal, the $\mathrm{pH}$ of the contents (Smith \& Sissons, 1975) is near the optimum for the enzyme ( $\mathrm{pH} 45-6 \cdot 0$; Grosskopf, 1965). The extent of lipolysis in samples taken from the abomasum was normally found to be in excess of $20 \%$ (Otterby, Ramsey \& Wise, 1964a; Siewert \& Otterby, 1971). However, in the absence of saliva it was one-quarter of normal (Ramsey \& Young, 196I $a$ ): this activity probably being due to residual traces of salivary lipase, as gastric secretion contains no lipase (Toothill, Thompson \& Edwards-Webb, 1976) and regurgitated intestinal and pancreatic enzymes are not normally found in the abomasum (Otterby, Ramsey \& Wise, $1964 \mathrm{~b}$ ). Lipid digestion is completed by the action of pancreatic lipase, but little is known about the relative contributions of salivary and pancreatic lipase to fat digestion.

Salivary lipase preferentially releases butyrate (Harper, I957; Grosskopf, I965; Hamilton \& Raven, 1973). Despite the paucity of butyrate linkages (I04 moles/

* Paper no. I: Br. F. Nutr. (1976), 36, 439. 
I000 moles of fatty acid) in cow's milk, Ramsey \& Young (196 $a, b$ ) showed that salivary lipase produced more free butyric acid than higher fatty acids and that the reverse was true for pancreatic lipase (EC 3.I.I.3). By contrast, the specificity of both enzymes was reported to be the same by Gooden (1973). It is known that pancreatic lipase produces relatively more free fatty acids and much smaller but nearly equal amounts of di- and monoglycerides (Constantin, Paséro \& Desnuelle, 1960) whereas salivary lipase produces far more diglycerides than monoglycerides (Siewert \& Otterby, 1968). This has been confirmed by Olivecrona, Hernell, Egelrud, Billström, Helander, Samuelson \& Fredrikzon (1973), who also found almost equal amounts of diglycerides and free fatty acids in the stomach contents of rats. These findings would be expected from the observation that salivary lipase only attacks diglycerides slowly, in contrast to pancreatic lipase (Richardson \& Nelson, 1967). However, Gooden (1973) found no difference in the proportion of the various partial glycerides resulting from the action of salivary and pancreatic lipases.

The action of the two enzymes might be expected to be additive, but according to Olivecrona et al. (1973) for rat enzymes, salivary lipase action actually enhances the action of pancreatic lipase.

The present study was made to resolve the conflicting evidence about the pattern of lipolysis caused by the two enzymes. We have determined the rate of release of the major fatty acids from the fat in cow's milk by salivary and pancreatic lipase acting in vitro in approximately physiological proportions using analytical techniques capable of determining the free fatty acids from $C_{4}$ to $C_{18}$. The pattern of lipid classes formed by the action of the enzymes has been compared. A study has also been made of the release of fatty acids from cow's milk fat by the successive action of salivary and pancreatic lipases.

\section{EXPERIMENTAL}

\section{Surgery and collection of materials}

Salivary and pancreatic lipases were obtained from a surgically prepared, male Friesian calf. An oesphageal fistula was fitted at $10 \mathrm{~d}$ by the method of Chapman \& Hamilton (1962), and a pancreatic re-entrant cannula was fitted at $29 \mathrm{~d}$ by the method of McCormick \& Stewart (I967). The calf was fed cow's milk twice daily using a nipple feeder.

Salivary lipase was obtained at $5 \mathrm{I} \mathrm{d}$ by giving the calf water to drink before the morning feed. The fluid containing saliva (salivary lipase solution) was collected from the open fistula. Pancreatic juice was obtained at 44,45 and $5 \mathrm{I} \mathrm{d}$ immediately after the morning feed by disconnecting the two ends of the cannula, and collecting the juice from the proximal end in a glass vessel cooled on ice. The saliva solution and pancreatic juice were stored at $-20^{\circ}$ until required. Before use, the saliva solution was filtered through cotton wool to remove mucous.

A bile pool was prepared by bulking the gall-bladder bile obtained at the slaughter of six, approximately 6 month-old calves. The $\mathrm{pH}$ value of the bile was adjusted to 6.7 (Expts I and 2) and 6.5 (Expt 3).

The substrate used was raw, bulk whole milk from the Institute herd. 


\section{Analytical methods}

Lipids. The samples were extracted with chloroform-methanol $(2: \mathrm{I}, \mathrm{v} / \mathrm{v})$, by the technique of Folch, Lees \& Sloane Stanley (1957) as used for blood serum (Nelson \& Freeman, 1959). The lipid classes were separated by thin-layer chromatography using silica gel $\mathrm{H}$ (E. Merck AG, Darmstadt, Germany) as described by Tuckley \& Storry (1974).

Fatty acids. Free fatty acids $\left(\mathrm{C}_{4: 0}-\mathrm{C}_{18: 2}\right)$ were extracted with diethyl ether and absorbed onto an ion-exchange resin (Amberlyst A29; BDH Ltd, Poole, Dorset) as described by Edwards-Webb (1975). Both the unesterified fatty acids and the fatty acids in the other lipid classes were converted to their methyl esters using, respectively, hydrogen chloride in methanol ( $100 \mathrm{ml} / \mathrm{l}$ ) and boron trifluoride in methanol ( $140 \mathrm{~g} / \mathrm{l}$ ) reagent (BDH Ltd) and analysed by gas-liquid chromatography with heptanoic and heptadecanoic acids (Fluka AG Buchs, Switzerland) as internal standards as described by Edwards-Webb (I975).

Incubations. Solutions of salivary and pancreatic lipases, and substrate were warmed to $37^{\circ}$ separately, before mixing and incubating in a shaking water-bath at $37^{\circ}$ in glass-stoppered conical flasks. Samples were withdrawn at intervals between 2 and $80 \mathrm{~min}$.

\section{Enzyme incubations}

Expt I. The release of free fatty acids from the fat in cow's milk after different incubation periods, and at different enzyme concentrations. Saliva solution or pancreatic juice were used as collected, or after dilution with water $(\mathrm{I}: \mathrm{x}, \mathrm{v} / \mathrm{v})$. All incubations were done in triplicate in $50 \mathrm{ml}$ flasks. For the salivary lipase test, $15 \mathrm{ml}$ raw milk and $15 \mathrm{ml}$ saliva solution were mixed and incubated $(\mathrm{pH} 6.7)$. For the pancreatic lipase test $\mathrm{I} 5 \mathrm{ml}$ raw milk and $\mathrm{I} 2 \mathrm{ml}$ water were mixed with $2.25 \mathrm{ml}$ bile, and $0.75 \mathrm{ml}$ pancreatic juice was added before incubation ( $\mathrm{pH} \mathrm{6.7).} \mathrm{For} \mathrm{control} \mathrm{incubations,}$ water replaced the enzyme solutions. Samples $(10 \mathrm{ml})$ were removed from each flask after 30 and $60 \mathrm{~min}$ for the determination of free fatty acids.

The individual fatty acid concentrations in the milk used as substrate were determined in a chloroform-methanol $(2: \mathrm{I}, \mathrm{v} / \mathrm{v})$ extract without separating the lipid classes.

Expt 2. The initial rates of release of free fatty acids from the fat in cow's milk and the relative molar concentrations of lipid classes produced by lipolysis. Incubations were done singly for salivary and pancreatic lipases, in $250 \mathrm{ml}$ flasks. After appropriate periods of incubation ro $\mathrm{ml}$ samples were removed for determination of triglycerides, diglycerides, monoglycerides and polar lipid classes, and further $10 \mathrm{ml}$ samples were taken for determination of free fatty acids.

For the salivary lipase test, $70 \mathrm{ml}$ raw milk and $70 \mathrm{ml}$ saliva solution were mixed for incubation ( $\mathrm{pH} 6.7$ ). Samples were taken for analysis after 2, 5, 10, 20, 40 and $80 \mathrm{~min}$ incubation. In control incubations, water replaced the enzyme solution.

For the pancreatic lipase test, $70 \mathrm{ml}$ milk $(\mathrm{pH} \mathrm{6.7)}$, $10.5 \mathrm{ml}$ bile, $56.0 \mathrm{ml}$ water and $3.5 \mathrm{ml}$ pancreatic juice were mixed and incubated. Samples were removed for 
analysis after $5,10,20,40$ and $80 \mathrm{~min}$ incubation. In control incubations, milk, bile and water, or water, bile and pancreatic juice were used.

Expt 3. The release of free fatty acids from the fat in cow's milk by salivary lipase and pancreatic lipase acting consecutively. Milk $(40 \mathrm{ml})$ and saliva solution or boiled saliva solution $(40 \mathrm{ml})$ were incubated $(\mathrm{pH} 6.5)$ for $30 \mathrm{~min}$ in $100 \mathrm{ml}$ flasks. For free fatty acid determination a $10 \mathrm{ml}$ sample was removed from each flask. The incubation mixtures remaining in the flasks were re-adjusted to $\mathrm{pH} 6.5$. Three $20 \mathrm{ml}$ portions were taken from each flask and to these were added respectively: (I) $0.5 \mathrm{ml}$ pancreatic juice and $\mathrm{I} .5 \mathrm{ml}$ bile, (2) $0.5 \mathrm{ml}$ boiled pancreatic juice and I. $5 \mathrm{ml}$ bile, (3) $2 \mathrm{ml}$ water only. After a further $30 \mathrm{~min}$ incubation, II $\mathrm{ml}$ were taken for determination of free fatty acids. The complete procedure using the same enzyme solutions was done twice in the same day. The concentration of individual fatty acids in the raw milk was also determined as described for Expt $\mathrm{I}$.

\section{RESULTS}

Expt $\mathrm{I}$. The release of free fatty acids from the fat in cow's milk after different incubation periods and at different enzyme concentrations

The free fatty acids were corrected for any free acids not formed by either salivary or pancreatic lipases. The extent of lipolysis for each fatty acid was calculated as the ratio, fatty acid released by lipolysis:fatty acid originally contained in the substrate. The mean values for the extent of lipolysis, with their standard errors, are given in Table I. The standard error of differences between periods of incubation within a dilution are based on the pooled interaction mean squares 'periods of incubation $x$ flasks' for diluted and for undiluted enzyme solution, with four degrees of freedom. The standard error of differences between dilutions within a period of incubation is a pool of the above interaction mean squares and the error mean squares 'between flasks' for diluted and undiluted enzyme solution with four degrees of freedom.

Both salivary and pancreatic lipases released butyric acid more rapidly than any other acid (Table 1). The longer-chain acids were released by pancreatic lipase at broadly similar rates, about one-third to half that of butyrate. Salivary lipase also released the medium-chain fatty acids $\left(\mathrm{C}_{8}-\mathrm{C}_{12}\right)$ at rates comparable with that of pancreatic lipase, but had a marked inability to lipolyse longer-chain acids $\left(>C_{14}\right)$. The molar proportion of the released fatty acids that consisted of butyric together with caproic acid from each dilution, and at each period of incubation is shown in Table 2. Butyric and caproic acids together accounted for nearly two-thirds of the acids released by salivary lipase, and less than one-third of the acids released by pancreatic lipase (Table 2).

Expt 2. The initial rates of release of free fatty acids from the fat in cow's milk, and the relative molar concentrations of lipid classes produced by lipolysis

At each sampling time the total of each fatty acid present in the incubation mixture was calculated by summing the amounts found in the triglyceride, diglyceride, monoglyceride, free fatty acid and polar lipid fractions. The free acid produced by 
Table I. Expt I. Proportion of individual fatty acids released from the fat in cow's milk by salivary and pancreatic lipases $(E C$ 3.I.I.3) (undiluted and diluted I:I (v/v) with water) after incubating for 30 and $60 \mathrm{~min}$ at $37^{\circ}$

(The values within a dilution are the means of three separate incubations, and are expressed as $\mathrm{mg}$ unesterified fatty acid/g total fatty acid for each fatty acid, with their standard errors)

\begin{tabular}{|c|c|c|c|c|c|c|}
\hline \multirow[b]{2}{*}{ Fatty acid } & \multicolumn{2}{|c|}{ Undiluted } & \multicolumn{2}{|c|}{ Diluted } & \multirow[t]{2}{*}{$\begin{array}{l}\text { SE of } \\
\text { difference } \\
\text { between } \\
\text { incubation } \\
\text { periods } \\
\text { within a } \\
\text { dilution } \\
\text { (4 df) }\end{array}$} & \multirow[t]{2}{*}{$\begin{array}{c}\text { SE of } \\
\text { difference } \\
\text { between } \\
\text { dilutions } \\
\text { within an } \\
\text { incubation } \\
\text { period } \\
\text { (4 df) }\end{array}$} \\
\hline & $30 \min t$ & $60 \min t$ & $30 \mathrm{~min} \dagger$ & 60 mint & & \\
\hline \multicolumn{7}{|c|}{ Salivary lipase } \\
\hline $4: 0$ & 374 & 5 II & 246 & 377 & $9 \cdot 7$ & $7 \cdot 7$ \\
\hline $6: 0$ & 145 & 210 & 95 & 149 & $3 \cdot 3$ & $3 \cdot 2$ \\
\hline $8: 0$ & 83 & 123 & 53 & 87 & $I \cdot 2$ & $I \cdot 5$ \\
\hline $10: 0$ & 86 & 124 & 56 & $\cdot 90$ & $1 \cdot 6$ & $I \cdot 8$ \\
\hline $12: 0$ & 94 & 138 & 60 & IOI & $3 \cdot 3$ & 3.9 \\
\hline $14: 0$ & 38 & 60 & 24 & 40 & 0.5 & $I \cdot I$ \\
\hline $16: 0$ & I5 & 28 & 8 & I 8 & 0.5 & 0.7 \\
\hline $16: 1$ & $3^{8}$ & $6 I$ & 30 & 44 & $2 \cdot 6$ & $3 \cdot 2$ \\
\hline $18: 0$ & 7 & 16 & 3 & 9 & 0.3 & 0.5 \\
\hline $18: 1$ & I I & 21 & 6 & 13 & 0.3 & 0.5 \\
\hline $18: 2$ & 16 & 26 & 8 & 19 & $2 \cdot 3$ & $2 \cdot 2$ \\
\hline \multicolumn{7}{|c|}{ Panqreatic lipase } \\
\hline $4: 0$ & 436 & 738 & 126 & 244 & $5^{\cdot 6}$ & $7 \cdot 9$ \\
\hline $6: 0$ & 282 & 523 & 48 & 112 & $8 \cdot 3$ & 6.9 \\
\hline $8: 0$ & 292 & 470 & 47 & 104 & $5^{-8}$ & $6 \cdot 3$ \\
\hline $10: 0$ & 217 & 340 & 48 & 98 & 3.5 & 5.5 \\
\hline I 2:0 & 170 & 278 & 42 & 85 & $4 \cdot 5$ & 5.4 \\
\hline $14: 0$ & I2I & 196 & 3 I & 62 & 4.0 & $3 \cdot 8$ \\
\hline $16: 0$ & 169 & 264 & 46 & 87 & $6 \cdot 2$ & 5.1 \\
\hline I6:I & 158 & 250 & 33 & 77 & $7 \cdot 6$ & $6 \cdot 6$ \\
\hline I 8:0 & 204 & 327 & 52 & 99 & $8 \cdot 8$ & $7 \cdot 6$ \\
\hline I $8: \mathrm{r}$ & I 87 & 292 & 44 & 84 & $5 \cdot 2$ & 54 \\
\hline I $8: 2$ & 179 & 251 & 43 & 78 & $8 \cdot 8$ & 13.8 \\
\hline
\end{tabular}

Table 2. Expt 1. The molar proportion comprised by butyric and caproic acids of the total fatty acids released from the fat in cow's milk by salivary or pancreatic lipases (EC 3.I.I.3) (undiluted and diluted I:I (v/v) with water) after incubating for 30 and $60^{\prime \prime} \min$ at $37^{\circ *}$

(Values are expressed as mmol unesterified $\mathrm{C}_{4: 0}+\mathrm{C}_{B: 0} / \mathrm{mol}$ unesterified total fatty acids)

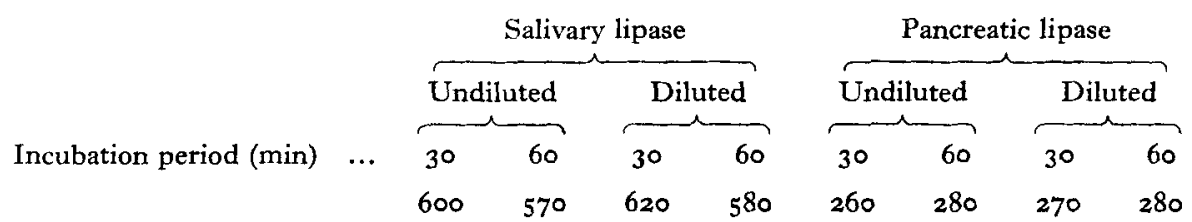

* For details of experimental procedures see p. 433 . 


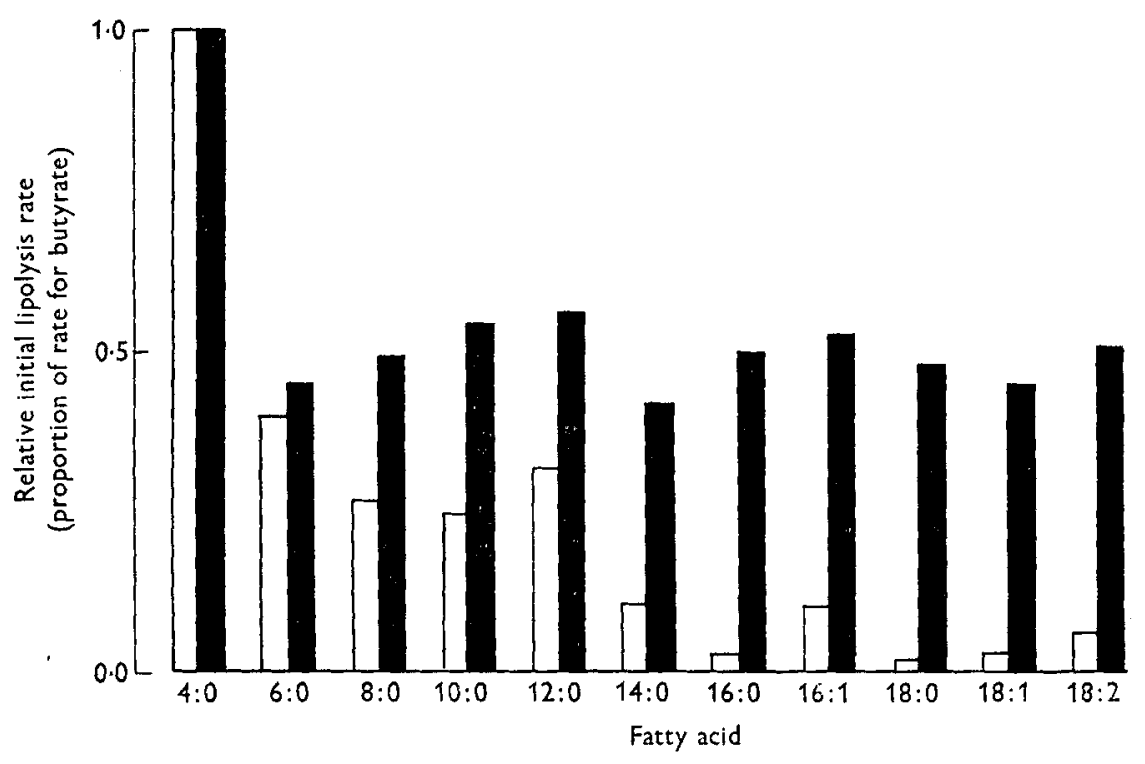

Fig. I. Expt 2. Relative initial rates of lipolysis for individual fatty acids of the fat in cow's milk, released by calf salivary and pancreatic lipases $(E C 3.1 .1 .3)$ in vitro (proportion of initial rate for butyrate, which was taken as equal to $1 \cdot 00$ ). ( $\square$ ), Salivary lipase; ( 1 ), pancreatic lipase. For details of experimental procedures, see p. 433 .

lipolysis was corrected for any acid originally present by subtracting the appropriate control values. The proportion of each fatty acid lipolysed was plotted $v$. period of incubation. The tangents to the curves at the start of incubation gave the initial rates of lipolysis for the individual fatty acids. The rates, expressed as a proportion of the rate relative to butyrate which was taken as equal to $\mathrm{I}^{\circ} \mathrm{O}$, are shown diagrammatically in Fig. I. The similarity to the pattern of release found in Expt $I$ is evident. With salivary lipase butyrate was released most rapidly, followed by caproate, and at a relatively slower but fairly constant rate the acids $\mathrm{C}_{8}-\mathrm{C}_{12}$, and again acids $>\mathrm{C}_{14}$ were released very slowly. Pancreatic lipase, apart from the high rate for butyric acid, released all other acids at a fairly constant rate (approximately half the rate for butyrate). The amounts of each lipid class produced by salivary and pancreatic lipases were calculated as mmol lipid-class fatty acid per mol total fatty acid, and these values plotted $v$. period of incubation are shown in Fig. 2. The results show that salivary lipase produced about equal amounts of diglyceride and free fatty acids, whereas pancreatic lipase produced mainly free fatty acids and relatively little diglyceride. Both enzymes produced only a little monoglyceride.

Expt 3. The release of free fatty acids from the fat in cow's milk by salivary lipase and pancreatic lipase acting consecutively

The extent of lipolysis for each fatty acid was calculated as in Expt 1 . The release of individual fatty acids from milk fat incubated for 30 min with salivary lipase only, and after a further $30 \mathrm{~min}$ following the addition either of water, bile + boiled 


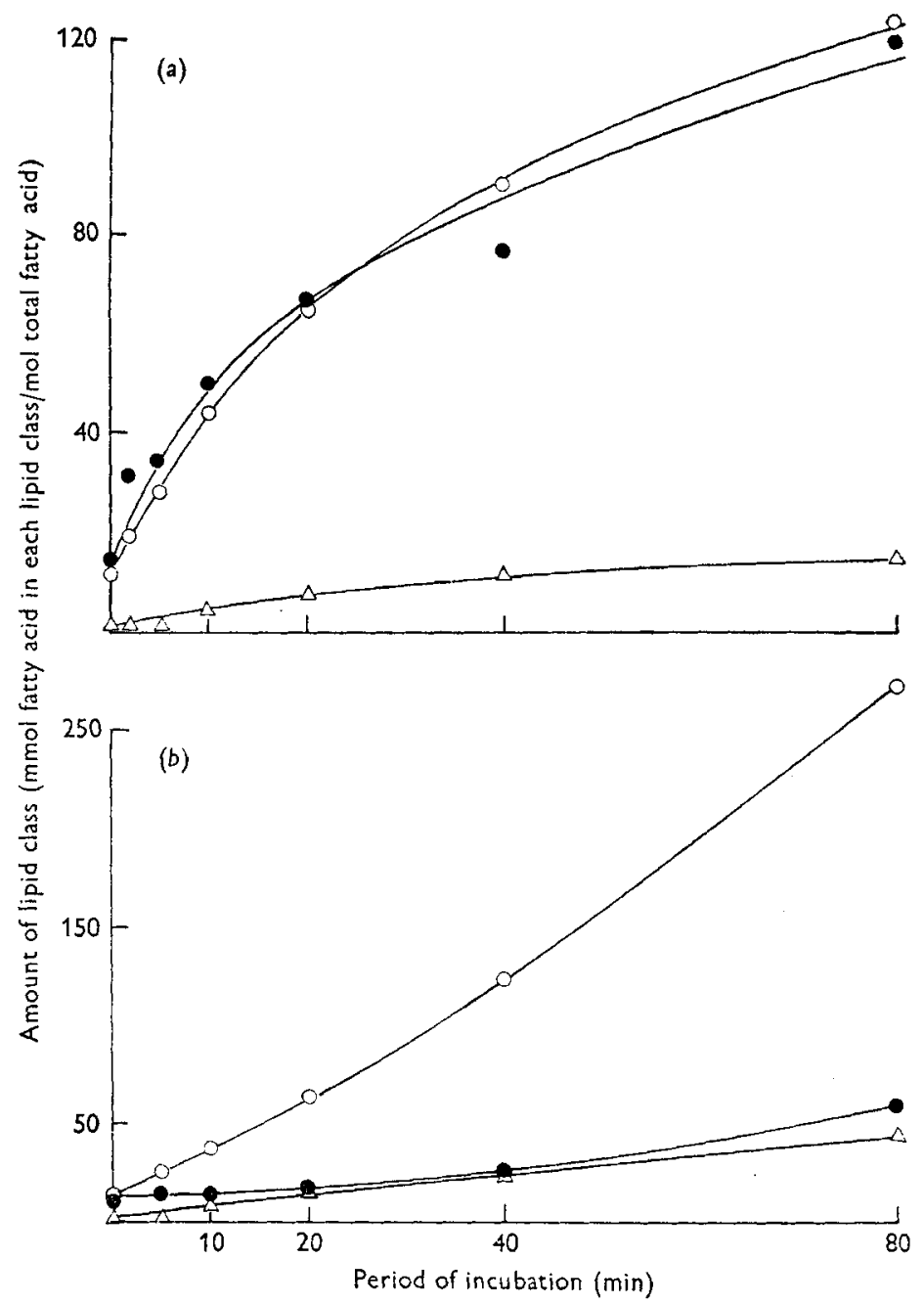

Fig. 2. Expt 2. Amounts of lipid classes produced by lipolysis of the fat in cow's milk by calf salivary lipase $(E C$ 3.1.1.3) $(a)$, and pancreatic lipase (b) (mmol fatty acid in each lipid class/mol total fatty acid) after different periods of incubation (min). (O), Free fatty acid; (๑), diglyceride fatty acid; $(\triangle)$, monoglyceride fatty acid. For details of experimental procedures, see p. 433 .

(inactive) pancreatic juice or bile + pancreatic juice is shown in Table 3. Continued incubation for a further $30 \mathrm{~min}$ with salivary lipase alone caused further lipolysis, but this was reduced by the addition of bile. The addition of both bile and pancreatic lipase increased lipolysis considerably. In the instances of palmitic, stearic and oleic acids continued incubation with salivary lipase alone produced about a 2 -fold increase in free acid, but with pancreatic lipase the corresponding increases were 5 -fold for palmitic and oleic acids, and 8-fold for stearic acid.

When milk fat is first incubated with salivary lipase the subsequent release of fatty acids by pancreatic lipase is greater than in the absence of an initial salivary lipase treatment (Table 4). The table also shows the 'enhancement' in lipolysis due 
Table 3. Expt 3. Proportion of individual fatty acids released from the fat in cow's milk by salivary lipase acting for 30 and 60 min (A) or salivary lipase acting for $60 \mathrm{~min}$ but with the addition of bile and pancreatic lipase after 30 min $(\mathrm{B})^{*}$

(Values are the means of two determinations, and are expressed as mg unesterified fatty acid/g total fatty acid for each fatty acid)

\begin{tabular}{|c|c|c|c|c|}
\hline \multirow[b]{2}{*}{$\begin{array}{l}\text { Incubation conditions } \\
\text { Fatty acid }\end{array}$} & \multicolumn{2}{|c|}{ A } & \multicolumn{2}{|c|}{ B } \\
\hline & $30 \mathrm{~min}$ & $60 \mathrm{~min}$ & $\begin{array}{c}\text { Inactive } \\
\text { pancreatic lipa }\end{array}$ & $\begin{array}{l}\text { Active } \\
\text { reatic lipase }\end{array}$ \\
\hline $4: 0$ & 433 & $63 \mathrm{I}$ & 489 & 704 \\
\hline $6: 0$ & $14 I$ & 225 & 165 & 333 \\
\hline $8: 0$ & 80 & 137 & 103 & 296 \\
\hline 10:0 & 85 & 140 & 99 & 232 \\
\hline $12: 0$ & 94 & 148 & 108 & 197 \\
\hline $14: 0$ & $3^{8}$ & 66 & 49 & 127 \\
\hline $16: 0$ & 15 & 29 & 27 & 152 \\
\hline $16: 1$ & 40 & 57 & 49 & 154 \\
\hline $18: 0$ & 8 & 19 & 20 & 172 \\
\hline $18: 1$ & 12 & 24 & 22 & 149 \\
\hline I 8:2 & 21 & 34 & 28 & 136 \\
\hline
\end{tabular}

- For details of experimental procedures see p. 434 .

Table 4. Expt 3. Proportions of individual fatty acids released from the fat in cow's milk by pancreatic lipase (EC 3.1.1.3) acting for 30 min preceded by inactive (boiled) salivary lipase (A), or active salivary lipase acting for $30 \mathrm{~min}(\mathrm{~B})$, and the enhancement of release $(B: A)^{*}$ (Values for $A$ and $B$ are means of two determinations, and are expressed as
$\mathrm{mg}$ unesterified fatty acid/g total fatty acid for each fatty acid)

$\begin{array}{cccc}\text { Fatty acid } & \text { A } & \text { B } & \text { B:A } \\ 4: 0 & 271 & 215 & 0 \cdot 8 \\ 6: 0 & 118 & 168 & 1 \cdot 4 \\ 8: 0 & 113 & 193 & 1 \cdot 7 \\ 10: 0 & 103 & 133 & 1 \cdot 3 \\ 12: 0 & 81 & 89 & 1 \cdot 1 \\ 14: 0 & 59 & 78 & 1 \cdot 3 \\ 16: 0 & 84 & 125 & 1 \cdot 5 \\ 16: 1 & 78 & 105 & 1 \cdot 4 \\ 18: 0 & 100 & 152 & 1 \cdot 5 \\ 18: 1 & 86 & 127 & 1 \cdot 5 \\ 18: 2 & 79 & 108 & 1 \cdot 4\end{array}$

* For details of experimental procedures see p. 434 .

to pre-incubation with salivary lipase ('enhancement ratio'; amount of fatty acid released when pre-incubated : amount of fatty acid released in the absence of preincubation) for each fatty acid; for all acids except butyric the value was $>\mathrm{I} \cdot 0$.

\section{DISCUSSION}

The relative rates of release of the fatty acids showed that under the conditions of our tests salivary lipase had a marked preference for short- to medium-chain acids, particularly butyric and caproic which comprise almost two-thirds of the 
total fatty acids released. A very low rate of lipolysis of long-chain acids was found for all periods of incubation, and dilutions tested, as well as initially. This is in agreement with the findings of Ramsey \& Young (196r $b$ ) who determined, using milk fat, the rate of release of butyric relative to higher fatty acids and also the relative rate of release of several fatty acids from their esters with 2-naphthol. Similar conclusions were reported by Hamilton \& Raven (1973) who used pure triglycerides as substrates with salivary lipase.

The production of free fatty acid, together with diglyceride as the other major lipolysis product indicates that salivary lipase releases only a single fatty acid from each triglyceride molecule. This is in agreement with the findings of Richardson $\&$ Nelson (1967) who showed that the rate of lipolysis of dibutyrin by 'pregastric esterase' was one-twentieth of the rate when pancreatic lipase was used. The positional analysis of bovine milk fat by Pitas, Sampugna \& Jensen (1967) showed that $84.6 \%$ of butyric and $58.0 \%$ of caproic acids were esterified at the $s n-3$ position of glycerol. The present findings, confirming the preponderant release of these acids, also suggests that salivary lipase may have a preference for the $s n-3$ position. This is supported by the work of Paltauf, Esfandi \& Holasek (1974) who showed, using a synthetic enantiomeric triglyceride, that rat lingual lipase attacks the $s n-3$ position approximately twice as fast as the $s n$-I position, whereas pancreatic lipase gave similar rates of attack at both $s n-\mathrm{I}$ and $s n-3$ positions.

In our experiments pancreatic lipase showed a much more uniform rate of release of all fatty acids than did salivary lipase, and although butyric acid was the most readily lipolysed acid, in agreement with the recent findings of Chandan, Khan \& Shahani (1976), butyric together with caproic acids only contributed a little over one-quarter of the total free acid. This finding, and also the relatively small amount of diglyceride produced, is in agreement with the work of Sampugna, Quinn, Pitas, Carpenter \& Jensen ( 1967 ) who showed that pancreatic lipase has an inter-molecular preference for shorter-chain triglycerides, typically those containing butyric acid. These authors found that when this acid was liberated from either of the primary positions of glycerol, the other primary position was lipolysed at a similar rate.

When milk fat was incubated for $\mathrm{I} h$ with salivary lipase the rate of lipolysis in the first $30 \mathrm{~min}$ of incubation was greater than in the second $30 \mathrm{~min}$ of incubation, and even during the second $30 \mathrm{~min}$ period the extent of lipolysis of long-chain acids ( $>\mathrm{C}_{14}$ ), which together comprise two-thirds of milk fatty acids, remained low. However, a relatively large increase in the extent of lipolysis of long-chain acids was found when pancreatic lipase also was present during the second $30 \mathrm{~min}$ incubation period. This demonstrates that the over-all extent of lipolysis by salivary lipase is limited by its inability to release long-chain acids. However, other factors may also tend to limit the action of salivary lipase, such as low abomasal $\mathrm{pH}$ value (Siewert \& Otterby, I970), proteolysis of the lipase (Cohen, Morgan \& Hofmann, 197I) and inhibition by bile, as demonstrated in the present study.

Our results in vitro would appear to be at variance with those of Gooden (I973) who concluded that the pattern of release of fatty acids from cow's milk fat is similar for both salivary and pancreatic lipases. However, his conclusions may in part be 
attributed to the use of unphysiologically high levels of enzyme, and also to his failure to measure the release of short-chain free fatty acids.

In our experiment all acids except butyric showed an enhancement ratio $>$ I when lipolysis by pancreatic lipase was preceded by salivary lipase action. The low value for butyric acid may be due to the large proportion $(430 \mathrm{mg} / \mathrm{g}$ ) of this acid already released by salivary lipase. We are at this stage unable to explain this enhancement, either from our own, or from published work. However, the ability of salivary lipase to 'prime' the substrate for pancreatic lipase may be of considerable importance to the very young calf ( $<7 \mathrm{~d}$ of age) since it has been shown that pancreatic lipase activity is at a relatively low level at this age (Huber, Jacobson, Allen \& Hartman, 1961).

The authors wish to thank Dr H. L. Buttle for the surgical preparation of the calf, and Mr P. Ganderton for its care and management, and Dr D. Hewitt for the statistical treatment of some of the results.

\section{REFERENCES}

Chandan, R. C., Khan, I. M. \& Shahani, K. M. (1976). F. Dairy Sci. 59, 847.

Chapman, H. W. \& Hamilton, F. J. (1962). Aust. vet. F. 38, 400 .

Cohen, M., Morgan, R. G. H. \& Hofmann, A. F. (1971). Gastroenterology 60, r.

Constantin, M. J., Paséro, L. \& Desnuelle, P. (1960). Biochim. biophys. Acta 43, 103.

Edwards-Webb, J. D. (1975). F. Sci. Fd Agric. 26, 1943.

Folch, J., Lees, M. \& Sloane Stanley, G. H. (1957). F. biol Chem. 226, 497.

Gooden, J. M. (1973). Aust. F. biol. Sci. 26, 1189.

Grosskopf, J. F. W. (1965). Onderstepoort $\mathcal{F}$. vet. Res. 32, 153.

Hamilton, R. K. \& Raven, A. M. (r973). F. Sci. Fd Agric. 24, 257.

Harper, W. J. (1957). F. Dairy Sci. 40, 556.

Harper, W. J. \& Gould, I. A. (1955). F. Dairy Sci. 38,87.

Huber, J. T., Jacobson, N. L., Allen, R. S. \& Hartman, P. A. (1961). F. Dairy Sci. 44, 1494.

McCormick, R. J. \& Stewart, W. E. (1 967). F. Dairy Sci. 50, 568.

Nelson, G. H. \& Freeman, N, K. (1959). F. biol. Chem. 234, 1375.

Olivecrona, T., Hernell, O., Egelrud, T., Billström, A., Helander, H., Samuelson, G. \& Fredrikzon, B. (r973). In Dietary Lipids and Postnatal Development, p. 77 [C. Galli, G. Jacini and A. Pecile, editors]. New York: Raven Press.

Otterby, D. E., Ramsey, H. A. \& Wise, G. H. (1964a). F. Dairy Sci. 47, 993.

Otterby, D. E., Ramsey, H. A. \& Wise, G. H. (I964b). F. Dairy Sci. 47, 997.

Paltauf, F., Esfandi, F. \& Holasek, A. (1974). FEBS Lett. 40, 119.

Pitas, R. E., Sampugna, J. \& Jensen, R. G. (1967). J. Dairy Sci. 50, 1332.

Ramsey, H. A., Wise, G. H. \& Tove, S. B. (1956). F. Dairy Sci. 39, 1312.

Ramsey, H. A. \& Young, J. W. (I96ra). F. Dairy Sci. 44, 2227.

Ramsey, H. A. \& Young, J. W. (1961 b). F. Dairy Sci. 44, 2304.

Richardson, G. H. \& Nelson, J. H. (I967). F. Dairy Sci. 50, I06.

Sampugna, J., Quinn, J. G., Pitas, R. E., Carpenter, D. L. \& Jensen, R. G. (1967). Lipids 2, 397.

Siewert, K. L. \& Otterby, D. E. (1968). F. Dairy Sci. 5r, 1305.

Siewert, K. L. \& Otterby, D. E. (1970). F. Dairy Sci. 53, 57 I.

Siewert, K. L. \& Otterby, D. E. (1971). F. Dairy Sci. 54, 258.

Smith, R. H. \& Sissons, J. W. (1975). Br. F. Nutr. 33, 329.

Toothill, J., Thompson, S. Y. \& Edwards-Webb, J. D. (1976). Br. F. Nutr. 36, 439.

Tuckley, B. \& Storry, J. E. (1974). Lipids 9, 493 .

Wise, G. H., Miller, P. G. \& Anderson, G. W. (1940). F. Dairy Sci. 23, 997.

Wise, G. H., Miller, P. G. \& Anderson, G. W. (r947). F. Dairy Sci. 30, 499. 